\title{
WOMEN POLITICAL PARTICIPATION IN PEACEBUILDING IN SOUTHERN THAILAND
}

\author{
Amporn Marddent ${ }^{1}$ \\ Faculty of Liberal Arts of Walailak University \\ Email: mamporn@gmail.com
}

\begin{abstract}
This article explores the historical, practical and consequences of women in political participation in the peace process during the ongoing conflict negotiations from 2004 until the present time. The author examines the cases of the Malay Muslims, who are the dominated populations in this violent conflict region and a significant minority group in Thailand, and the non-Malays who are also active in paving the way for peace making in various forms of activity in southern border provinces of country. Gender analysis of the intertwined ethno-religious and political identities of the Malays and non-Malays demands a need to reorientation of the concept of peace and security which contributed to illuminate deeply understanding of the society during conflict resolution.
\end{abstract}

Keywords: Malay Muslim Women, Political Participation, Peacebuilding, Southern Thailand

\section{INTRODUCTION: THE MALAYS IN THE SOUTH}

The Muslim population in Thailand is a minority. Islam is the country's second largest religion. ${ }^{2}$ The position of Muslims in modern Thai polity in existing academic works at the turn of the century was confined to the Malay Muslims of southern Thailand and the relationship between the political construction that rejects the legitimacy of the secularized Buddhist polity ${ }^{3}$ and Thai Buddhist

${ }^{1}$ The author would like to aknowledge the support by Thai Research Fund (TRF) for this research-based article and expresses her deepest grattitute. It is also the intention of the author to credit the Annual International Conference on Islamic Studies (AICIS) 2017 organized by the Ministry of Religious Affair of the Republic of Indonesia in which the author was invited to present the paper. It was held in Jakarta on 22-25 November 2017

${ }^{2}$ Academics and Muslim authorities like the Chularajmontri consider the official Muslim population estimated by the state (4.5 percent) to be on the low side. For more information, see National Statistics Office of Thailand (2005), Bajunid (1999) and Yusuf (1998).

${ }^{3}$ For the term "secularized Buddhist polity, see Somboon Suksamran, "Buddhism, Political Authority, and Legitimacy in Thailand and Cambodia" in Buddhist Trends in Southeast Asia (1993, 101-144). Interference has occurred since the Anglo-Siamese Treaty of 1909. For example, during the of King Vajiravudh (1910-25) - who emphasized allegiance to the Thai nation, monarchy, and Buddhism - the Compulsory Primary Education Act of 1921 required all Malay children to attend Siamese primary school for at least four years. 
political cultures. In the broader context of Muslim studies in Thailand, however, Forbes and Scupin made valuable contributions to understanding Muslims on the national level, especially within the historical and political contexts of modern Thailand (Bajunid, 1999).

Before the great waves of Chinese immigration in the early $20^{\text {th }}$ century, Muslims were the largest single minority in Thailand and were by no means restricted to the southern provinces. Bajunid $(1988,2005)$ distinguishes between 'assimilated' and 'unassimilated' Muslims in Thailand. The former consist of diverse ethnic groups such as the Arabs, Pathans, and Thai-Malays. The 'unassimilated' group consists of ethnic Malay Muslims in the southern border provinces. With regard to the Malays living in central Thailand, they were brought there from the former Malay state of Patani as prisoners-of-war in 1785, when the Northern Malay Sultanate of Patani was conquered by Siam (Wyatt, 1984: 151). Many were retained as slaves and principal courtiers of the king and settled in villages near Bangkok. ${ }^{4}$

Thai-Pattani relations are a source of chronic controversy of nation-state issues in the southernmost boundary which Thongchai Winichakul (1994) called the 'geo-body' of nation. Melayu Pattani, who are Muslims, struggle like other minorities over the notion of 'Thai-ness, since the conceptions of Thai chauvinism and geo-body resulted in a territorially and culturally unified Siam nation-state with fixed borders. Malay ethnic identity as expressed in terms of language, dress, education, history, and custom was consistently discouraged by the state. ${ }^{5}$

The Thai state has attempted to replace Malay ethnicity with a religious label, 'Thai Muslim' or 'Thai Islam,' hoping that this change would contribute to the overall goal of assimilation. The notion of an Islamic state of Pattani, which is closely related to the Pattani Malay ethnic nationalist movement, is another factor within the contemporary politicization of religion accommodating the violent conflict in southern Thailand (Jory, 2007; Davisakd, 2008; Thanet, 2008; Kobkua, 2008; Yusuf, 2007b; Gilquin, 2005; Gowing, 1985). It is generally understood that the problem concerning the

Another important case occurred during the World War II under the leadership of Marshal Phibunsongkram, when Thai nationalism was imposed in the southern border provinces. Chaiwat Satha-Anand describes how the police tore up Malay attire and beat people, men and women, who wore it (Satha-Anand 2008, 161).

${ }^{4}$ The people of the former Patani sultanate were usually referred to as Melayu (Malay), even during the reign of the modernizing King Chulalongkorn who abolished the Patani sultanate and absorbed of the former sultanate's territories into the Thai state.

${ }^{5}$ The perception of Malayness, marked by language, cultural practices, religion and an important shared sense of history of being a people conquered by the Siamese (Thai Buddhist) powers, has caused the Malays to see themselves as a distinct ethnic group vis-àvis Thai Buddhists. 
identity of the kingdom's subjects began when the state embraced nationalism as an essential part of its nation building, starting in the first quarter of the twentieth century.

Consequently, Malay Muslims in Thailand consider themselves different in ethnoreligious terms. Socio-political and cultural aspects of life are interpreted and perceived through the lens of ethnic identity. The Thai political invasion in the region in the early twentieth century led to unprecedented cultural confrontation in the area between the Malays and the new Thai bureaucrats sent from Bangkok to rule them. Moreover, the rising of Malay nationalism in Southeast Asia in the 1940s has furthered this ethnic divide in southern Thailand.

By using the terms 'Thai Muslim' or 'Thai Islam,' the Thai state moved in the subsequent period to embrace religious plurality. However, Buddhism remained closely associated with Thai identity ${ }^{6}$, while Malay Muslims still appear to resist assimilation into Thai society, despite the fact that their identities underwent a great deal of transformation. The political instability of the post-Second World War period also threatened to undermine Thailand's claim for political legitimacy in the South. Malay Muslim elites tried to gain advantages from the political situation in the area, for example by demanding the institution of Muslim family law, educational quotas, and dress codes.

The revitalization of Islam in Thailand in the 1970s was related to a new political phenomenon in the earlier age of imperialism when the modern Thai state elites opened Siam for inter-state relations. ${ }^{7}$ Although Thailand was independent, it was compelled to adopt policies similar to the other colonial neighbours in order to survive amidst colonizing powers. The sense of a subsiding identity crisis arose from the growing familiarity with western cultures among the Thai elite. The outbreak of a communist insurgency in 1950s brought a new identity crisis for the Thai upper class. At the same time, the reworking of Thai history concerning

${ }^{6}$ According to Surin Pitsuwan (1985: 68-70), King Wachiravut's rule marked the beginning of a long and torturous struggle to widen the sphere and deepen the level of autonomy for the Malay-Muslims of Patani based on specific ethnic differences. However, the very nature of the Thai state and its bureaucratic set-up did not permit such royal policy to be fully promulgated. The bureaucracy was dominated by Thai Buddhists, who maintained their sense of ethnic Thai chauvinism. These bureaucrats could not be expected to conscientiously carry out state policies that would respect regional differences and preserve ethnic autonomy. Special treatment of the Malay-Muslims of Patani would have contradicted the single most ideological contribution the king himself made to the Thai nation: nationalism. Between the two objectives of the cultivation of a Thai national identity (with the Thai language, Thai religion-Theravada Buddhism, and Thai culture implied by it) and the preservation of a minority's separate identity, the former was always the priority of the Thai bureaucrats.

7 The country's name was changed from Siam to Thailand during the tenure of the first Phibulsongkhram government (1938-44). During this period, which coincided with World War II, the country was dominated by an energetic and aggressive brand of nationalism which influenced both domestic and foreign policies. 
ethnic minorities by various intellectuals has brought the Muslim youth into negotiations with the 'homogenous' Thai identity discourse (Jory, 2003).

\section{PIOUS PATANI MALAY MUSLIM WOMEN IN TRANSITION}

In searching for contemporary historical literature on Malay Muslim women and the opportunities for access to political participation, I found a pioneering study in the 1980s by Thai anthropologist Chavivun Prachuabmoh found that ethnic identity maintenance is based primarily on women's activities in public and domestic spheres. ${ }^{8}$ She proposed an interesting argument of ethnicity based on cultural background-linguistic, religious, and symbolic features-among the Thai, Chinese, and Malay in Thailand's southernmost provinces.

Chavivun argues that Malay identities cannot be sufficiently explained by history or cultural symbols. The Thai Muslims of the Deep South, she writes, maintain their distinctive ethnicity through various social organizations such as family, kinship, community, friendship networks, and religious education. Women have the primary responsibility for maintaining ethnic symbols such as clothing and language. They are expected to minimize interaction with outsiders and their strong opposition to intermarriage. Chavivun views the ethnic relations of the Malays as gendered. Women are expected to uphold prohibitions against intermarriage and to cover their bodies more completely than are nonMuslim women. Moreover, women are more inclined to maintain their cultural symbols better than men. They may have greater influence on their children because their teaching of how to be nayu is a more intimate and emotional process, while male ethnicity is more heavily oriented towards formal organizations. Men spend more time outside the household and have avoidant relationships with their children (1989: 113-150).

Even though Patani historical studies portrayal an interesting aspect of the Sultanah or the queens during 1584 until the mid-1600s which was constituted as the golden age of Patani, there is a certain formal political context within. The four women Ratu (Queens) ${ }^{9}$ had been involved a top position in political realm. The situation relates to Patani's independence from consolidating Buddhist Siamese Kingdom of Ayutthaya who succeeds in defending their land. However, there is

${ }^{8} \mathrm{Her}$ first study is a doctoral dissertation entitle, The Role of Women in Maintaining Ethnic Identity and Boundaries: A Case of Thai-Muslims (Malay Speaking Group) in Southern Thailand.

${ }^{9}$ Ratu Hijau (the Green Queen), Ratu Biru (the Blue Queen), Ratu Ungu (the Violet Queen) and Ratu Kuning (the Yellow Queen) expanded their political power to Kelantan and Terengganu. See, Ibrahim Syukri. History of the Malay Kingdom of Patani. Translated by Bailey Conner and John N. Miksic, Southeast Asia Series. Ohio: Centre for International Studies, Ohio University, 1985. 
no treat with concerning an agenda for peacemaking from the queens. Toward the end of the century when Patani was partly as a consequence of Siamese invasions in 1674 and 1688, a Chinese visitor observed that "Patani is a country ruled by a Queen and not a country of military prowess." 10 McCargo, a British political scientist who completed research in Pattani a decade ago and released Tearing Apart the Land: Islam and Legitimacy in Southern Thailand (2008) among other several pieces, states that these former female Malay Sultanates ruled for a time. Moreover, there was no evidence that Pattani was ever governed by a council of Ulama. The Quran was also never used as the basic law in this area.

Moreover, I found a story of the recent group of the "Three Tiger Warriors" (Saam Taharn Sua)' story compelling, but unfortunately there were no documents clarify their political participation role in the Malay Muslim community. This lack of documentation includes the debate over the relationship between ethnicity and the Malay Muslim women's peace movement, which has not been acknowledged. According to Ismail Ali, the former director of the College of Islamic Studies, Prince of Songkla University, Pattani, the name Saam Taharn Sua was bestowed by local Malay Muslims. The word tiger (sua) refers to women who have the capacity to seek and teach religious knowledge in the community, as well as to establish their own study group. They also helped each other to campaign to vote for one of their younger "inner circle" leader, Maraim Samoh or kak Yae who is a friend of Saam Taharn Sua, to succeed in election under Social Action Party (Phak Kit Sangkhom), however, fail to gain election in $1976 .{ }^{11}$ This failure did not devalue their leadership in collaborating with Malay Muslim community to have women's involvement in political party.

In the aftermath of the failure of Social Action Party in Pattani, kak Yae turned into dakwah, religious mission, activity. She set up an orphaned girl school in her own community in the beginning of 1990s which is usually supported by the people of the surrounding villages, local religious leaders, and the three tiger warriors. Situations like this, in which Muslim women set up a group and empower themselves as well as other people through religious knowledge and affirm their leadership role in modern political arena, had never existed previously in southern border provinces of Thailand. Thus, the group challenges the traditional viewpoint of women leadership through sophisticated engagement in political activism and Islamic education.

${ }^{10}$ Lorraine M. Gesick. In the Land of Lady White Blood: Southern Thailand and the Meaning of History. Ithaca, NY: Southeast Asia Program, Cornell University, 1995.

${ }^{11}$ After October 14, 1973 uprising against the military dictatorship and the October 6, 1976 massacre of student movement or both October events provided spaces for a certain group of Muslim women in the South to be involved in political reform. In case of kak Yae, she was encouraged by her husband and local Malay politicians to be a candidate for Social Action Party right after her graduation from Malaysia. 
The activity of kak Yae with the Saam Taharn Sua' support represented a major shifted in structures of Malay culture, political role, and Islamic authority. In Malay society and the village in particular, people's relationship is very close. The views and actions of leaders effected commoners strongly. The alim, religious leader, is at the same time political leader of the village. Kak Yae has curtailed male domination in leadership, especially in core religious space- orphaned girl school-for decades. She holds the ultimate sources of Islamic knowledge, the Qur'an and the sunnah, in her school and classes. She pointed to the issue of female authority in seeking and sharing knowledge by choosing the frame of power and responsibility to strengthen society by referring to the hadith and the Qur'an ${ }^{12}$ and saying that "we are a part". For kak Yae, the increasing of women in attendance at prayers and lessons is a good sign of balancing women's right in Muslim community. Her role is played in religious and social leadership of the community.

Within the three tiger warriors group are three women who were recognized for their bravery as well as for their move towards leading a more religious life. The first woman, Hamidah Adae or kak Zu, was awarded an honorary doctorate of Islamic Studies from Fatoni University, the first private Islamic university in Thailand, in March 2015. In 2011, Hamidah retired from the College of Islamic Studies of Prince of Songkla University. However, she continues to play a role as an advisor of the Network of the Southern Muslim Women's Association. She was also often invited by Fatoni University to give lectures and share her knowledge with female halaqah (study groups).

Hamidah finished her upper secondary school secular education at the same time as thanawiyah or higher religious secondary level from Wattanatham Islam School, which is known as Por Ming Pondok, Pattani. ${ }^{13}$ It is important to note here that during the Sarit Thanarat government (1958-1963), Thailand attempted to integrate Malay-Muslim people into mainstream Thai society with new educational policies, which included transforming pondok into private Islamic schools in 1959. Consequently, it increased the number of Muslim women who began enrolling in private Islamic schools (Tawee et al. 1987). In the case of Hamidah, she was a female religious teacher at Por Ming Pondok for several years before continuing her studies abroad with the support of the school, community, and her family in particular. Her grandfather is a respected tok guru, or religious teacher, of the community.

${ }^{12}$ The Hadith that kak Yae mentioned is about continuously seeking knowledge until death and the Qur'an, 20:114 “..., O Lord advance me in knowledge...”.

${ }^{13}$ Islamic private school offered religious and secular knowledge which the government-approved schools were divided into four levels, elementary or primary school curriculum (Ibtidaiyah); the middle school curriculum (Mutawassitah); the secondary (Thanawiyah) and the higher secondary (Thanawiyah Khassah) school curriculums. 
Khadijah Binti Abdul Rahman or kak Joh is the second of the Three Tigers. She is currently an educational administrator of her family's school, Bamrung Islam School or Bra-o Pondok, in Pattani. The school was initially run by Khadijah's father, Abdurrahman Japakiya, who is a well-known traditionalist orthodox religious teacher, and later by other male members of Japakiyas family. Ismail Lutfi Japakiya, Khadijah's brother, the most respected contemporary religious leader of the Saudi style salafism in southern Thailand ${ }^{14}$, later became chairman of the school. He is the founding of rector of Fatoni University (formerly known as Yala Islamic University). At the present time, Khadijah is the administrator of the pre-primary school Bamrung Islam School. She continues to organize female halaqah with school teachers and the members of religious women's activist group.

Hamidah and Khadijah wanted to gain more Islamic knowledge as well as recognition among men and the community when they experienced teaching at pondoks. In the 1970s the best place for Muslim women from the Deep South to facilitate higher religious education in terms of common culture and language as well as proximity was Malaysia. Yayasan Pengajian Tinggi Islam Nilam Puri or Nilam Puri Islamic Higher Education Institute (Nilam Puri, for short) in Kota Bahru, Kelantan was a popular destination for many Muslim youth from southern Thailand to continue their religious study after the thanawiyah level. ${ }^{15}$ Hamidah soon earned a scholarship for a master's degree in Shariah (Islamic Law) at al-Azhar University in Cairo, Egypt. She has been acknowledged by a number of Muslim scholars as a knowledgeable female who was the first Pattani Muslim woman to achieve a master's degree from al-Azhar University. Khadijah returned to her father's pondok after obtaining an ijazah certificate on Islamic Theology and Community (Usuluddin Dan Kemasyarakatan) from Nilam Puri in $1987 . .^{16}$

The last leading member of the Three Tigers is Maesonk Yusok or kak Sonk, a tough, brave, outspoken woman. Maesonk is an active teacher at Sas Sanu Patham School or Bana Pondok, Pattani, where she finished her thanawiyah. Maesonk was not able to continue her own studies at Nilam Puri as planned because of poverty, but achieved her goal vicariously by providing her nieces

${ }^{14}$ Salafism is one of Islamic reform movement that urged Muslim fellows to return to, and strictly follow the sacred sources, and purify Islamic ideas and practices from later innovation (bid'ah). The Salafi movement has advocated for a social change through tarbiyyah (education) by working within the Thai constitutional framework.

${ }^{15}$ Yayasan Pengajian Tinggi Islam Nilam Puri, the first Islamic higher education in Kelantan was established by the state government in 1965. The institute offers B.A. for two departments, Shariah (Islamic Law) and Education. See Abdullah, 1973: 29-75.

${ }^{16}$ Ijazah means license or authorization. It is an identical instrument of academia in the highest degree of Islamic educational system from the classical period of Islam. See, J. Meri and J. Bacharach, Medieval Islamic Civilization, volume 1 an Encyclopedia (New York: Routledge, 2006), 201-2. 
and nephews with funding for higher education. Apart from teaching, Maesonk obtained administrative experience by running a profitable cooperative school store for more than a decade. She organized Muslim youth and women's camps in the villages every semester with the help of Khadijah, Hamidah, Mariam and other leading Malay Muslim women in the Deep South. The camp, held during the semester break when they returned to Pattani. It focused on Islamic knowledge and practices, particularly women's roles and duties according to Islam.

Maesonk and Hamidah chose not to get married although a number of men approached them. They relied on the precedence set by Umme Kulsoom, daughter of Abu Bakr, a senior companion of Prophet Muhammad who refused a marriage proposal by Umar, an influential caliph. While Maesonk accepts that Islam encourages Muslims marry. However, to be a single woman is not fitna, disorder or immorality. She worries about understanding of people over fitna, which often focused on women troublesome. However, she feels that forced marriage against a person's will is not an Islamic tradition. Hamidah views the criticism leveled against her for not being married as a challenge, particularly in her role of active agent in the resurgence of a religious movement. She counters by providing a reinterpretation of the scripture regarding unmarried life as the opportunity to remain autonomous and dedicate her time to social and religious devotion.

Hamidah, Maesonk, and Khadijah began teaching in their own villages and the pondoks with which they are connected in the mission of Islamic revival. They chose to provide lessons independently without the assistance of traditional male religious leaders, except for an aspiring reformist scholar, Ismail Lutfi Japakiya. Their efforts to reach out to young Malay women in the three provinces of Southern Thailand, and Pattani in particular were acknowledged for promoting widespread shifts in religious practice among the locals. They later directed groups of Malay Muslim women in adopting a more Islamic observant lifestyle rather than focus merely on women attire.

The historical context of Muslim women's veiling is indirectly related to their movement, which reveals the diversity and complexity of the narratives involved. As discussed earlier, the three tiger warriors were not involved with demonstrators at the Yala Central Mosque. ${ }^{17}$ After finishing their degrees in Malaysia in the midlate 1980s, they returned to Pattanti to educate the younger generation about Islam.

${ }^{17}$ One of the most prominent signs of Islamic reawakening in Thailand is linked with the Muslim women's identity marker, the headscarf, which is often called hijab. The so-called 'Yala Teacher Training College Incident' (1987- 1988) in Yala Province discussed below caused the emergence of a more conscious 'self' identification within the Muslim community in Thailand when Muslim women were not allowed to wear the veil in educational institutions. More information, please see "Hijab and Moments of Legitimation: Islamic Resurgence in Thai Society.", 1994. 
While they kept their circle away from the Yala hijab incident, they recognized that the movement led to the appearance of a symbol of Islamic femininity widely and publicly.

They based their political agenda in the realm of religious authority to interpret the texts from a women's perspective, and became intellectuals who transmitted knowledge to others and encouraged their students to dress modestly. However, they also attempted to go beyond the outward appearance of clothing, by emphasizing religious education and philosophy and how it can empower women through knowledge. Hamidah states that there are various concepts that define Muslim women's dress. While some terms have been used widely, for instance, hijab (veil) and niqab (face veil), but these terms are not mentioned in the passages of the Quran. Hamidah has observed a certain term, veil. It became a measure of Muslim women's aurah or the intimate parts of body which must be covered with clothes.

For Hamidah, this is not a specific term limits only on women's body. Thus, she believed that women should have the same religious education as men. She referred to the verses of the Quran ${ }^{18}$ which particularly revealed the equal rights and spiritual between men and women. Learning was commendable. It helped women to improve their knowledge and change environment also through self-disciplines. Preaching Islam for the group and their allies was based on good religious education and moral. Moreover, Hamidah raised the case of A'isha, the wife of the Prophet who was a Hadith-narrator and believed to have reported and taught 2,210 traditions. ${ }^{19}$

In practice, these women provided literacy course and basic of Quranic study groups for women and girls in particular, beside male and female youth in their own communities. Their efforts began by reaching out to the Muslim women and younger females in leading educational religious circle (halaqah) in the privacy of homes, neighbours' homes, and educational institutions. There is a

18 "O mankind! reverence your Guardian-Lord, Who created you from a single person created of like nature his mate and from them twain scattered (like seeds) countless men and women; reverence Allah through Whom ye demand your mutual (rights) and (reverence) the wombs (that bore you): for Allah ever watches over you." (4:1), "If any do deeds of righteousness be they male or female and have faith, they will enter Heaven, and not the least injustice will be done to them." (4: 124) and "For Muslim men and women for believing men and women for devout men and women for true men and women for men and women who are patient and constant for men and women who humble themselves for men and women who give in charity for men and women who fast (and deny themselves) for men and women who guard their chastity and for men and women who engage much in Allah's praise for them has Allah prepared forgiveness and great reward." (33: 25).

${ }^{19}$ See also Spellberg, D. A. Politics, Gender, and the Islamic Past: The Legacy of A'isha bint Abi Bakr. (New York, Columbia University Press, 1993.) and Grey, Sarah, Women's Role as Teachers, Leaders, and Contributors to the Waqf in Damascus. (Research Report for Julia Meltzer, 14, 2014). 
leader of each group who received another training course weekly or monthly by the three tiger warriors under the structure of family or cell (usrah). Consequently, relationship between halaqah leaders and usrah trainers was a close one.

The environment that Muslim women could not only read or recite but also discuss the ideas related to the Quranic verses instead of depending religious specialists is a new system of learning among Malay Muslim women in southernmost provinces of Thailand. Joining the three tiger warriors and alliance halaqah meant becoming modern in religious practices. They referred to a particular verse of the Quran that women were also called to participate in social reform..$^{20}$ Women gathered to pray and learn together as well as recognized as religious leaders. However, they experienced tension from the criticised of traditional Malay Muslims in the area. They insisted that there should be no obstacles for female teachers and preachers, family and community should gladly allow them to pursue the activity.

The core of the three tiger warriors' ideology is empowering women to religious knowledge and education, women's attire and veil became an issue for justification when they confronted with traditional religious leaders who possess as the legislative body of religious authority. Regarding Muslim women's identity marker, Hamidah observed that before the 1980s, many Malay Muslim women in the southernmost provinces of Thailand wore short- or threequarter-sleeved blouses with a long wrap skirt or sarong. The traditional baju kurung, a kneelength blouse worn over a long bright floral patterned skirt, was worn on special occasions, such as weddings and certain Islamic celebration days known as hari raya. ${ }^{21}$ These dress patterns were considered modest according to Malay tradition.

The idea of veiling appeared among educated middle-class modernists and elite traditionalists. Working-class women, however, were much less involved in the movement. Unveiled women who dress in kain lepas are recognized as not being influenced by the spirit of Islamic resurgence. The hijab movement in Thailand has changed similarly to the way it has in many other Muslim communities. Aihwa Ong applied Soheir Morsy's term "depeasantization” to describe middle-class women and religious nationalism in Malaysia. She described the scene in Sungai Jawa, where groups of village girls enter teacher colleges and universities wearing Islamic clothes. In the view of village elders, the religious outfit is

${ }^{20}$ The Qur'anic verse 16:97 revealed Muslim women and their ability to exercise freedom of religious and other life choices. ("Anyone who works righteousness, male or female, while believing, we will surely grant them a happy life in this world, and we will surely pay them their full recompense (on the Day of Judgment)for their righteous works").

${ }^{21}$ Hari Raya consists of several celebration days, including Eid al-Fitri, the end of the fast, Ramadan, and Eid alAdha, the feast of the sacrifice or hajj celebration day. 
inappropriate for life in the village. It is the costume of an educated woman and a symbol of depeasantization. It has replaced the body-fitting batik sarung-kebaya of the days before Islamic resurgence. ${ }^{22}$

The narratives of women's religious identity reflect valuable and diverse viewpoints regarding the emergence of the veil in Thai society through selfportraits and explanations by Muslim women activists who were involved both directly and indirectly with the gradual change in ideas about Muslim women's role in religious life. Even though current pious Islam is intended to be visible in public, which for women is through the veil, veiling itself is not the main issue that the three tiger warriors and their networks point to as the foreground of the reform agenda.

Islamic resurgence in Malaysia is rooted in the early 1970s and resulted in economic growth and the expansion of educational opportunities among Malaysians. At the same time, rivalry among Islamization projects has resulted in an intensification of Malay gender differences, segregation and inequality. Pressures for an Islamic state have been especially strong within Kelantan, where the opposition Islamist party, the Pan-Malayan Islamic Party (PAS, Parti Islam SeMalaysia) has had considerable electoral success. In 1965, the Kelantan state government established an institute of Islamic Higher Learning known as Yayasan Pengajian Tinggi Islam Nilam Puri, which was the first Islamic higher education institution in Kelantan (Stivens, 2006).

Hamidah and Khadijah, who came from Pattani, enrolled in religious studies in order to improve their knowledge. Studying at Nilam Puri enabled them to experience a new atmosphere that addressed the students' enthusiasm for Islamic studies at a higher education level. Moreover, they participated in Islamic student groups and Islamic missionary activities known as dakwah. Students who participated in dakwah activities also organized halaqah (study groups) at Nilam Puri to discuss political Islam.

These leading women recognize themselves as initiated female informal political leaders in southern Thailand who brought certain changes and knowledge to their communities. Hamidah does not deny that there is resistance from traditionalist members who have accused her and other Muslim women in the reform network of devaluing Malay cultural norms and replacing them with Wahhabism. ${ }^{23}$ The women encountered with resistance from Islamic

${ }^{22}$ See Ong, "State Versus Islam: Malay Families, Women's Bodies and the Body Politic." in Ong, Aihwa and Peletz, Michael G. (eds.). Bewitching Women, Pious Men: Gender and Body Politics in Southeast Asia. Berkeley: University of California Press. 1995:159-194.

${ }^{23}$ The Wahhabi movement led by Muhammad Ibn Abd al-Wahhab of the eighteenth and early nineteenth century, gave rise to variegated Salafi reform movement offshoots, ranging from political activism - whose main aims are to capture state power through violent 
traditionalist members who resent them for devaluing Malay cultural norms and replacing them with Wahhabism. However, women have been criticized far less than have male reformist leaders. Purportedly, the movements backing the Three Tigers are also influenced by the salafi and Muslim Brotherhood movement. It showed an emergent Islamic radicalism on a global level in local context.

In addition, the reformist movement has had subtle influence on religious educational reform. ${ }^{24}$ Khadijah, in our conversation, also notes a significant impact of reformist trends on Islamic education in which women play a strong role. In her case, she works at her father's pondok and provides support and administrative assistance to Dr. Ismail Lutfi, who is currently involved in enhancing higher Islamic education. Khadijah closed the conversation by emphasizing the process of tarbiyah, which can gradually lead to changes in women. She believes that female leadership in political and peace process implementation scheme in present days became an inadvertent fashion in the Deep South Thailand.

\section{WOMEN DURING THE CURRENT WAVE OF VIOLENT CONFLICT}

I mentioned specifically earlier about the Three Tiger Warriors group's activity in relation to Islamic revitalization during the last two decades. While the insurgency of ethnoregionalist tension in the new wave of violent conflict, since 2004, have represented the tide of resentment in this region. The conflict is primarily the components which the Malay Muslims at the southern border provinces and the Thai state are essentially fighting. Historically, Malay Sultanate of Patani, which was established in the 13th century as a Buddhist Sultanate before Islam became the dominant faith in the early 15th century. In 1900s, the

means in order to enforce Islamic law from the top - to political quietism, whose adherents believe that religious change must come in stages, and that the current context necessitates tarbiyyah (education and cultivation to encourage proper Muslim practices). Aryud Yahprung (2014: 18) states in his recent doctoral study that Islamic reform in the southern border provinces of Thailand entered a new chapter when a group of Pattani male doctoral students who graduated from institutions in Saudi Arabia returned to Thailand in the late 1980s. These leading reformists are Ismail Ali (1950-), Abdul Halim Saising (1947-), Jihad bin Muhammad (1951- 2002), and Ismail Lutfi Chapakia (1950-present). They launched a loose network of Islamic reformism and called themselves the salafi.

${ }^{24}$ The Salafi group in southern Thailand which I referred to in Muhammad Ilyas's study earlier, emphasizes the reform of the Muslim community by reforming Muslim education. On the one hand, they set up Islamic schools, an Islamic university, and other learning institutions, such as language colleges, Islamic educational foundations, and printing houses. On the other hand, they propagated their Islamic reformism through the informal learning process of mosque-based private lectures, study circles, and preaching through local radio stations, and the Internet (Ibid: 8). See also Farish A. Noor in The Madrasa in Asia: Political Activism and Transnational Linkage (2008: 141-167). 
Thai state alternated between implementing strategies of assimilation and accommodation. The Thai state has continued its goal of incorporating the Malay citizens into an overarching Thai identity. Within this period, spontaneous and sporadic rebellions emerged, and Malay populations struggled against state authority. The current insurgency is also associated with regional economic disparities, unemployment, crime, and illegal drug use.

The attempts to establish dialogue as a way towards political solution have been made since $2005 .{ }^{25}$ The groups of women who are the major victims of the unrest also attempt to find alternative paths to build up peace in their society. Studies suggest that Muslim and non-Muslims women in this region are very heavily engaged with local women's networks, associations, civil society organization and non-governmental organizations. ${ }^{26}$ The groups tend to be led by highly capable and well educated middle-class women, who have university degree, and student volunteers from local universities. They also train women from the villages through various workshops and projects that often have support from national and international organizations that are engaged in peacebuilding efforts. For example, "Wanita: Women's Power for a Better Society" Project is the development plan that had been carried out during 2011-2014 to expand the network of local permanent service for women and children who had been mostly affected by violence.

In this part, I explore the continuum of the activity of the three tiger warriors' network particularly their idea of peace process. According to different vision and framework between women in the Islamic reformation movement and the grassroots movement, the notion of peacebuilding consequently carries into various foundations. The former group of women's movement focuses on the inner sentiment, which the leaders equate with takwa, the feeling of inner peace. Malay ethnicity becomes deessentialized, however, religious identity of being Muslim women have maintained through faith purification. The greater influence on the young generations from their teachings of how to be peace builder is a

${ }^{25}$ McCargo, D. Southern Thailand: From Conflict to Negotiations, Lowy I nstitue for International Policy, 2014.

${ }^{26}$ A.K. Molnar, "Chapter 22: Women's Agency in the Malay Muslim Communities of Southern Thailand" in P. Liamputtong, ed., Contemporary Socio-Cultural and Political Perspectives in Thailand. 2016: 350; Joint CEDAW Shadow Report 2016 "Situation of the Rights of Malay Muslim Women in Southern Thailand", 2017; Assessment Report The Development of Sustainable Community Extension Services for Women and Children Most-affected by the Unrest and Violence in the Southern Border Provinces of Thailand", 2015; JPF interview, "Malay Muslim women during the seminar on Access to Justice of Women in the Southern Border Provinces", 2014; The Political Participation of Village Woman Development Committee In Changwat Pattani, Master of Education thesis in Community Development Education, Prince of Songkla University, 2004.; Hafissa Salae, Muslim women amidst Conflict: The Transition from Victim to Peace Activist, MA Thesis, Sociology Department of Sociology and Anthropology, Thammasat University, 2010. 
more intimate with the inner disposition. They believe that to fight for a better inner spirit of trust in God could lift women's capacity in responding to peaceful society. Meanwhile, bringing ethnicity as a mean to build up society is heavily oriented towards organizations of the grassroots civil society.

According to Hamidah, she continues to play a key role in the network of the Southern Muslim Women's Association and the Council of Muslim Women's Organization Cooperation for Peace. These coordinating bodies for women's movement which she and her allies have been engaged provided a more explicit activity associated with the Al-Salam Institute of Fatoni University. This is an institute to promote an outreach program of Islamic activity. They view Muslim women's public activities involve in a frame of Islamic values.

Multaqa Muslimat, the conference of Muslim women, is an important case of women space which the Council of Muslim Women's Organization Cooperation for Peace relates their activity with the situation of the unrest. They have actively collaborated in the effort to expand dakwah activities and Islamic reform knowledge. Hamidah considers the meeting as a potential mean of creating a new network to support peace making process from religious perspective. The strategy of the Muslim women's movement could be changed according to local contexts, however. The impact of violent conflict in the region is one of the major forces that led Muslim women in the local reform movement, which is basically concerned with Islamic education, to be opened for a new frame of thought. Nonetheless, Hamidah asserts that engaging in the collective community still requires basic principles of the movement, that is, authentic expression of Islamic knowledge in corollary with tarbiyah and dakwah ideologies.

Networks of the three tigers and Council of Muslim Women's Organization Cooperation for Peace have also engaged with political and governmental bodies in conflict area, such as, the Pattani Provincial Administration Organization (Pattani $\mathrm{PAO})$. The pious Malay Muslim women desire for justice and peaceful society within their circles amidst several groups of women that have been established during the conflict situation in the region. Nevertheless, they have not engaged directly in peace-building efforts in collaborate with non-Muslim or Buddhist NGOs in the Deep South unlike the grassroots NGOs Muslim women's network that have collaborating openly with the non-believers.

Discussing further on the role of peacebuilding among the pious oriented Malay women, the emergence of boundaries among women of different Islamic orientations in southern Thailand indicates their presence in public space. This space was initially organized by the first generation of reform activists and Islamic intellectuals in coping with mechanisms vis-à-vis the predominant ideology according to women in Islamic discourse. My contention is that it still 
remains with some observable contexts from reformist women when they have involved in politics, reaffirmation of the inner peace narrative, and partnership of the movement.

The inner peace narrative is also a state apparatus of power to national development in modern Thailand. Additionally, the Thai state benefits from these "Muslim middle-class morals" and values as they have been interpreted by educated reformist Muslims. It contributes to the vigorous public forum with powerfully defined women as the hope of the Muslim community. Precisely because of the need for development in attempting to create moderate Muslim life during times of violent conflict, the state eventually has to engage with reformist Muslim women's activism. Observable scenes in regard to the venue of the conference in Pattani in 2010 and 2011, people who had been invited to the stage which selected different purposes were politically organized. Those who advocated Islamic reform to be applied for all women in Islamic history persuaded as the primary objective of the forum. They were friends and relatives of the scholars of Prince of Songkla University and Fatoni University as well as being represented by $\mathrm{PAO}$ institute.

\section{CONCLUSION}

As Abu-Lughod emphasizes on ethnography of the particular ${ }^{27}$, which I apply to discuss about people in the communities that I study to write about Malay Muslim women and conflict resolution, it is regarded as the study of the capacity for selfdetermination or agency of women in conflict area. Moreover, women's agency in Mahmood perspective demonstrated in embodied ethical practice. She applies it in her famous study of the Muslim women's mosque movement in Egypt that the movement typically involved some degrees of pietization in which the ordinary lives of Muslims were increasingly brought within a framework of devotion and pious practice. ${ }^{28}$

To understand the current situation of pious women's movement towards the issue of peacebuilding and their roles in Malay Muslim society, it could be reflected the identity of the minority. The dynamic of making peace in the context of ethnic Malay Muslim society proved the concept of inner peaceful mind of pious members. It functioned significantly among the groups of Islamic movement which adherence to its executive principles throughout the imagined peaceful society. Interestingly, they interpreted peace from a

${ }^{27}$ Abu-Lughod, Lila. "Writing Against Culture" in Recapturing Anthropology. Richard Fox, ed. Santa Fe, NM: School of American Research Press: 137-162.

${ }^{28}$ Mahmood, Saba. Politics of Piety: The Islamic Revival and the Feminist Subject. New Jersey: Princeton University Press, 2005. 
context-oriented perspective as a metaphor for the problems of the people in southern Thailand living with conflict. They finally offered a solution to the community in applying the implementation of the people in Islamic history.

My argument on the norms of piety was examined in the place where religious women were gathering to participate in order to build up peaceful society. Several activities of civil society organizations and non-governmental organizations working in Patani area have been portrayed in media and daily activity on the ground for almost a decade. The resources showed that pious salafi women groups in Pattani provided a reference on the growth of Islamization in different places, such as madani society with the discourse of civil society. Malay Muslim women's political participation in peace making appeared to be mainly actors in this instance. Women from the perspective of religious purification and inner peace were not singled out rather mingled with the state in the formal political arena.

It illustrated that civil society which could certainly contribute to intellectual and social activism as it is essential to develop alongside integrated Islamic education. Women's positions have made reference to the influence of the successful of peace building. The notion of agency as accommodated in the complexity of experiences of women was split from the subject-centered goals in an attempt to parochialize the constitutive relationship between action and embodiment, resistance and agency, and self and authority that inform judgment about nonliberal movements.

\section{BIBLIOGRAPHY}

Abu-Lughod, L. (1991). "Writing Against Culture" in Recapturing Anthropology. Richard Fox, ed. Santa Fe, NM: School of American Research Press: 137-162.

Bajunid, O. (1988). "The Muslims of Thailand: A survey" in A. D. W. Forbes (ed). The Muslims of Thailand. Volume 1. Historical and cultural studies. Bihar: Centre for South East Asian Studies: 1-30. (2005). "Islam, nationalism and the Thai state" in W. Sungannasil (ed). Dynamic diversity in south Thailand ). Chiangmai: Silkworm Books: 1-20.

CEDAW Shadow Report, (2016). "Situation of the Rights of Malay Muslim Women in Southern Thailand." 2017. 
Gesick, L. M. (1995). In the Land of Lady White Blood: Southern Thailand and the Meaning of History. Ithaca, NY: Southeast Asia Program, Cornell University.

Grey, S. (2014). Women's Role as Teachers, Leaders, and Contributors to the Waqf in Damascus. Research Report for Julia Meltzer, 14, 2014.

Ibrahim, S. (1985). History of the Malay Kingdom of Patani. Bailey Conner and John N. Miksic (trs). Southeast Asia Series. Ohio: Centre for International Studies, Ohio University.

Jory, P. (2006). "From "Pattani Melayu” to "Thai Muslim"” in ISIM Review Vol. 18 (Autumn 2006), pp. 42-43.

Mahmood, S. (2005). Politics of Piety: The Islamic Revival and the Feminist Subject. New Jersey: Princeton University Press, 2005.

McCargo, D. (2014). Southern Thailand: From Conflict to Negotiations. Sydney: Lowy Institute for International Policy.

Molnar, A.K. (2014). "Women's Agency in the Malay Muslim Communities of Southern Thailand" in P. Liamputtong (ed). Contemporary Socio-Cultural and Political Perspectives in Thailand. Springer, Dordrecht.

Ong, A. (1995). “State Versus Islam: Malay Families, Women's Bodies and the Body Politic." in Ong, Aihwa and Peletz, Michael G. (eds). Bewitching Women, Pious Men: Gender and Body Politics in Southeast Asia. Berkeley: University of California Press: 159-194.

Prachuabmoh, C. (1989). "The role of women in maintaining ethnic identity and boundaries: A case study of Thai-Muslims (the Malay-speaking Group) in South Thailand" in A. D. W. Forbes (ed). The Muslims of Thailand. Volume 2. Politics of the Malay-speaking south. Bihar: Centre for South East Asian Studies: pp. 113-150.

Satha-Anand, C. (1994). "Hijab and Moments of Legitimation: Islamic Resurgence in Thai Society." in C.F. Keyes, L. Kendall and H. Hardacre (eds). Asian Visions of Authority: Religion and the Modern States of East and Southeast Asia. Honolulu: University of Hawaii Press: 279-300.

Spellberg, D. A. (1993). Politics, Gender, and the Islamic Past: The Legacy of A'isha bint Abi Bakr. New York: Columbia University Press.

Suksamran, S. (1993). "Buddhism, Political Authority, and Legitimacy in Thailand and Cambodia" in T. Ling (ed). Buddhist Trends in Southeast Asia. Singapore: Institute of Southeast Asian Studies: 101-144.

Suwannathat-Pian, K. (2008). "National identity, and "Sam-Sams" of Satun, 
and the Thai Malay Muslims" in M. Montesano and P. Jory (eds). Thai south and Malay north: Ethnic interactions on a plural peninsula. Singapore: National University of Singapore Press: 155-172.

Wyatt, D. K. (1984). Thailand: A Short History. New Haven: Yale University Press. 